\title{
EARLY ORAL RE-FEEDING ON ONCOLOGY PATIENTS SUBMITTED TO GASTRECTOMY FOR GASTRIC CANCER
}

\author{
Realimentação precoce via oral em pacientes oncológicos submetidos à gastrectomia por câncer gástrico
}

Andressa Madalozo LAFFITTE, Camila Brandão POLAKOWSKI, Massakazu KATO

From Hospital Erasto Gaertner (Erasto Gaertner Hospital), Curitiba, PR, Brazil.

HEADINGS - Gastrectomy. Neoplasia. Diet.
ABSTRACT - Background: There is no advantage in maintaining patients on oral fasting after gastrointestinal elective resection. The early feeding up to $48 \mathrm{~h}$ can be beneficial, because it reduces infectious complications and hospital stay. Aim: Evaluate the evolution and tolerance of early oral diet in postoperative period after gastrectomy for gastric cancer. Methods: Anthropometric assessment was performed on the day of surgery, weight, height, body mass index and weight loss were measured. Acceptance of diet was evaluated as food intake (amount accepted) and gastrointestinal symptoms such as nausea, vomiting, constipation, diarrhea, abdominal distension, postoperative complications and hospital stay. Results: The sample consisted of 23 patients, 17 with partial gastrectomy and six with total gastrectomy. In the assessment of nutritional status $9 \%$ were malnourished, $54.5 \%$ normal weight, $9 \%$ overweight and $27.2 \%$ obese, but $54 \%$ had weight loss. There was good acceptance of the diet in $96,9 \%$ of the sample. Nausea and abdominal distension were present in $4,3 \%$ and $65.2 \%$ constipation. Surgical complications according to the Clavien scalle, $13 \%$ had grade $\mathrm{V}, 4.3 \%$ grade IIIA, $8.7 \%$ grade I and $73 \%$ did not have complications. The length of hospital stay was $5 \pm 2.2$ days. Conclusion: Early postoperative re-feeding in total and partial gastrectomy was well tolerated by patients.

\section{Correspondence:}

Andressa Madalozo Laffitte

E-mail: andressamli02@gmail.com

Financial source: none

Conflicts of interest: none

Received for publication: 26/03/2015 Accepted for publication: 25/06/2015

DESCRTORES: Gastrectomia. Neoplasia. Dieta.
RESUMO - Racional: Estudos mostram que não há vantagem em manter pacientes em jejum via oral após a ressecção eletiva gastrointestinal. A alimentação precoce até $48 \mathrm{~h}$ pode ser benéfica, pois diminui complicações infecciosas e permanência hospitalar. Objetivo: Avaliar a evolução e tolerância da dieta precoce via oral nos pacientes no pós-operatório de gastrectomia por câncer gástrico. Método: Foi realizada avaliação antropométrica no dia da operação aferindo peso, altura, índice de massa corporal e perda ponderal. A aceitação da dieta foi avaliada conforme ingestão alimentar (volume aceito) e sintomas gastrointestinais como náuseas, vômitos, obstipação, diarreia, distensão abdominal, complicações no pósoperatório e tempo de permanência hospilatar. Resultados: A amostra foi composta por 23 pacientes, sendo 17 com gastrectomia parcial e seis com total. A avaliação do estado nutricional demonstrou desnutrição em $9 \%$, eutróficos em $54,5 \%$, com sobrepeso $9 \%$ e com obesidade $27,2 \%$, porém $54 \%$ apresentaram perda ponderal. Houve boa aceitação da dieta em $96,9 \%$ da amostra. Dos sintomas avaliados 4,3\% apresentarem náuseas e distensão abdominal e 65,2\% de obstipação. Das complicações cirúrgicas, conforme a escala de Clavien, $13 \%$ apresentaram complicações grau $V$, 4,3\% grau IIIA, 8,7\% grau I e 73\% não apresentaram complicações. $O$ tempo de permanência hospitalar foi de $5 \pm 2,2$ dias. Conclusão: Realimentação precoce no pós-operatório de gastrectomia total e parcial foi bem tolerada pelos pacientes.

\section{INTRODUCTION}

$\mathrm{S}$ tomach cancer is the fourth most incident in Brazil for men and the fifth for women ${ }^{18}$, except for skin cancer. It occurs mostly in men and about $65 \%$ are over 50 years ${ }^{16}$.

For gastric cancer the most effective treatment is surgery 27,28 . The patient underwent surgery, which removes or reduces gastric camera, can display physiological changes represented by dumping syndrome, lower protein digestion, reduced absorption of vitamin B12 and intestinal malabsorption. These changes contribute to the progressive deterioration of the nutritional status and may lead to malnutrition, 3,17,26,28.

Patients undergoing gastric resection are generally able to initiate the oral intake from three to seven days postoperatively ${ }^{28}$, and it is common to have prolonged fasting in abdominal operations. Gastric decompression is often used for routine prevention of ileus, nausea and vomiting after surgery and potential anastomoses protection ${ }^{25}$, the assumption that bowel rest must occur to ensure the healing of digestive anastomoses with less risk.

Studies show, however, that there is no advantage in maintaining patients on oral fasting after the gastrointestinal elective resection. The early feeding up to $48 \mathrm{~h}$ can be beneficial because it reduces infectious complications and hospital stay ${ }^{21}$, and contributes to the healing of the anastomosis, faster recovery and is not related to complications after surgery ${ }^{25}$. Prolonged lack of food in the intestinal lumen generates 
mucosal atrophy, which may disrupt the intestinal barrier and promote bacterial translocation. When late, it may exacerbate the metabolic response to surgical trauma, with negative consequences for the nutritional status. The recommendation for feedback postoperatively for certain operations would be early onset (within 48 h) ${ }^{21}$.

The operations with presence of gastrointestinal anastomoses, enteroenteric, enterocolic or colorectal can start a liquid diet routine on the first day after surgery. Oliveira study showed that $74 \%(n=14)$ of the patients tolerated the volume of 300 $\mathrm{ml}$ by liquid diet meal $\mathrm{l}^{1,2,7,25}$.

The objective of this study was to evaluate the progress and tolerance the start of early oral diet (up to $48 \mathrm{~h}$ ) in patients in the postoperative period of total and partial gastrectomy demonstrating its applicability in hospital practice

\section{METHODS}

This study was submitted to the Research Ethics Committee of the institution being approved in accordance with the Protocol. 2270,2013 . It is a prospective, descriptive and transversal study. The research was conducted between the months July to December 2013 involving 41 patients of the Abdomina Surgery Department of Erastus Gaertner Hospital, Curitiba, PR, Brazil. The sample was of patients who underwent partial or total gastrectomy in the research period. Patients unable to perform anthropometric and with late-onset diet (more than $48 \mathrm{~h}$ ) were excluded.

The evaluation was conducted in three stages rising from the following data: 1 ) the day of the surgical procedure was checked for weight, height, body mass index (BMI), usual weight reported by the patient and the time lost weight (one week to six months) when compared to the current, percentage of weight loss (\% WLP) involuntary dividing the sample into two groups, adults (less than 60 years) and seniors; 2 ) on the first day of early oral feeding ( $2^{\text {nd }}$ day after surgery, because on the $1^{\text {st }}$ day were fasted) when they were asked about the acceptance and tolerance of the diet by volume ingested per meal and symptoms (nausea, bloating, vomiting, diarrhea and constipation), until hospital discharge; 3 ) up to 30 days after surgery to evaluate possible complications (fistula, dehiscence, pneumonia, deep vein thrombosis, respiratory failure, wound infection and evaluated the degree of complications according to Clavien scale (2009), which classifies surgical complications within seven classes (Figure 1). The normal postoperative course deviation, without pharmacologica

treatment, surgery, endoscopic or radiological. It is allowed the use of antipyretic drugs, antiemetic, antipyretic, analgesic, diuretic, electrolytes and physical therapy. Infection of open wounds.

II Pharmacological treatment, blood transfusions and parenteral nutrition.

Surgical, endoscopic or radiological intervention without the need for general anesthesia.

III B Surgical, endoscopic or radiological requiring general anesthesia. Need for intensive care, life-threatening, complications in the

IV A central nervous system. Dysfunction of an organ, dialysis.

Need for intensive care, life-threatening, complications in the

IV B central nervous system.

Multiple organ dysfunction

$\checkmark$ Death of the patient

\section{FIGURE 1 - Clavien's Scale ${ }^{11}$}

The first day of diet began on the second day after surgery with retrict-liquid diet, with a volume of $700 \mathrm{ml}$ fractionated into seven meals; on the second day of diet with the completeliquid diet, with a volume of $1100 \mathrm{ml}$ fractionated into seven meals and on the third day of diet with pasty-liquid diet, with a volume of $1450 \mathrm{ml}$ fractionated into seven meals (Figure 2), standing for the fourth till seventh day of diet and progressing to soft diet for 30 days, continuing to follow the diet in the nutrition clinic. This evolution occurred through some criteria as: well acceptance (greater than $75 \%$ ) of the volume offered and no vomiting. Re-admissions postoperatively added to the data collection form.

\begin{tabular}{|c|c|c|}
\hline Diet & Composition & Caloric intake \\
\hline Restrict-liquid & $\begin{array}{c}\text { Clear liquids } \\
\text { Low fat, fiber or sugars }\end{array}$ & $187,5 \mathrm{kcal} /$ day \\
\hline Complete-liquid & $\begin{array}{l}\text { Liquids (including milk) } \\
\text { Low-fat fiber }\end{array}$ & $323,3 \mathrm{kcal} /$ day \\
\hline Pasty-liquid & Liquefied food & $1005,7 \mathrm{kcal} / \mathrm{day}$ \\
\hline
\end{tabular}

FIGURE 2 - Protocol diets features for total and partial gastrectomy

The nutritional status was calculated by BMI (BMI=weight $(\mathrm{kg}) /$ height $\left(\mathrm{m}^{2}\right)$ and classified by the World Health Organization ${ }^{8}$ for adult and elderly. In \%PP was calculated using the formula: $\% \mathrm{PP}=[($ Usual $\mathrm{P}-$ Current $\mathrm{P}) \times 100] /$ usual PA. It was related the result of the percentage of weight loss and the time of such loss, based on the weight loss of $1-2 \%$ in a week, $5 \%$ in one month, $7.5 \%$ in three months and $10 \%$ in six months.

The data were tabulated in Microsoft Excel ${ }^{\circledR} 2007$ version, with descriptive analysis (frequency, percentage) and used software used was the SPSS 19.0.

\section{RESULTS}

In the six-month period was included 41 patients, 18 were excluded because they realized other concomitant surgical procedures (gastroenterostomy, esophagogastrectomy, jejunostomy and laparotomy), or because they started late diet, totaling 23 patients in the final sample. The age ranged from 48 to 84 years (mean 61 and median 60 ), in both genders. Seventeen (73.9\%) underwent partial gastrectomy, eight with lymphadenectomy, and six (26.1\%) to total gastrectomy with lymphadenectomy. According to clinical or pathological staging of the tumor, it was noted that almost half of the patients were in III (Table 1).

TABLE 1 - Tumor staging $(n=23)$

\begin{tabular}{lc}
\hline Staging & $\%(n)$ \\
\hline I & $17,4 \%(n=4)$ \\
\hline II & $8,7 \%(n=2)$ \\
\hline III & $43,4 \%(n=10)$ \\
\hline IV & $17,4 \%(n=4)$ \\
\hline Gist & $4,3 \%(n=1)$ \\
\hline Impossible to be staged & $8,7 \%(n=2)$
\end{tabular}

To evaluate nutritional status patients were divided into adults and the elderly. In adults $9 \%(n=1)$ of patients were malnourished, $54.5 \%(n=6)$ in eutrophic, $9 \%(n=1)$ were overweight and $27.2 \%(n=3)$ obesity, however, another data evaluated was the percentage of weight loss, which found that $54.5 \%(n=6)$ of adults have had this weight loss, with $27.2 \%$ $(n=3)$ in a serious way. In the elderly $41.6 \%(n=5)$ of patients were underweight, $41.6 \%(n=5)$ in eutrophic and $16.6 \%(n=2)$ overweight according to body mass index (BMI). Regarding weight loss $100 \%(n=12)$ showed that loss considering $58.3 \%$ were severely affected.

In assessing the evolution and acceptance of the diet protocol there was good acceptance in $95.6 \%$ on the restrictliquid diet on the $2^{\text {nd }}$ postoperative period ( $1^{\text {st }}$ day of diet); $95.2 \%$ in the complete-liquid diet on $3^{\text {rd }}$ postoperative period $\left(^{\text {nd }}\right.$ day of diet) and $100 \%$ in the pasty-liquid diet on the $4^{\text {th }}$ postoperative period ( $3^{\text {rd }}$ day of diet). Overall there was good acceptance of the diet (average 96.9\%) at all stages. 
When analyzing the symptoms after starting the diet, no patients presented vomiting or diarrhea in the relocation period, 4.3\% had nausea and/or abdominal distension and 65,2 had constipation. The length of stay ranged from 3 to 14 days (average $5 \pm 2.2$ ). Complications within 30 days of postoperative fistulas were $13 \%(n=3)$ and $17.2 \%(n=4)$ other complications (bronchospasm, sepsis, evisceration and vomiting). There were no other researched complications such as dehiscence, pneumonia, stroke, respiratory failure and wound infection.

In assessing the degree of postoperative complications according to Clavien's Scale, it was noted that not all grades were present in the sample. They were reported in grade $18.7 \%$, grade III A 4.3\%, grade V $13 \%$ and without complications $73.9 \%$.

The main complication, if compared with nutritional status, was the presence of fistula. Of the $13 \%(n=3)$ found $8.6 \%(n=2)$ were elderly with low weight and $4.3 \%(n=1)$ adults with some degree of obesity and mild weight loss. Among found fistulas, $8.6 \%(n=2)$ were in the esophagojejunal anastomosis and $4.3 \%$ $(n=1)$ in duodenal stump.

\section{DISCUSSION}

In this study it is clear that the majority of patients $(60.8 \%$, $\mathrm{n}=14$ ) was admitted with advanced disease according to clinical staging or pathological TNM ${ }^{15,28}$. Only $26 \%$ were underweight according to BMI for age, being almost half the expected according to the Brazilian Hospital Nutrition Examination Survey (IBRANUTRI); however, it should take into account that $78.3 \%$ of patients had weight loss. This item (percentage of weight loss) was not evaluated in the Murphy's study, however it concludes that the BMI alone is a poor indicator for gastrectomy for gastric cancer, where the malnutrition rate was only $12 \%$ of their sa mple $4,5,6,10,13,19,20,22,23,25$.

The displayed weight loss can be justified by food intake presented by patients according to tumor location. According IBNO (survey conducted in 16 Brazilian states and the Federal District) $6.5 \%(n=13)$ of patients with gastric cancer increased food intake, $71.7 \%(n=142)$ decreased and $21.7 \%(n=43)$ remained preserved. Another information weight related referred to the weight loss at $60.1 \%(n=80)$ on adults and $56.9 \%(n=37)$ on the elderly ${ }^{17}$.

In Oliveira study the early diet for patients with gastrectomy was accepted in $74 \%$ of cases, with low incidence of gastrointestinal symptoms. In 2011 Jo regards acceptance by $89 \%$ and only $8 \%$ with gastrointestinal symptoms ${ }^{20}$ approximately $96.9 \%$ in this study, the improvement in acceptance may be due to slight variation of the protocol (restrict-liquid, complete-liquid and pasty-liquid) ${ }^{25}$. It is noteworthy that the good thing is that these patients received caloric intake as early as possible, which also referenced by Hirao, where early diet group received higher caloric intake 3.2 days earlier than usual ${ }^{12}$.

Studies evaluating patients undergoing gastrectomy for gastric cancer claim that oral feeding on the first postoperative day is safe 20,19 .

Early feeding after operations involving resection and intestinal anastomosis can be conducted without risks and benefits as early discharge, lower incidence of infectious complications and lower hospital costs ${ }^{1}$, as well as Nakeeb shows that started early diet and got shorter hospital stay and less time to flatus, with good tolerance by patients $(75 \%)^{24}$.

Regarding vomiting - which did not occur in this study - it is controversial; was present in $13 \%$ in Nascimento (2002) paper, related to intestinal anastomoses ${ }^{4}$.

Another symptom found more frequently was constipation, taken after a period of over three days without stool. Approximately $65.2 \%$ of patients were constipated postoperatively, but it must be considered the preoperative fasting time and approximately $48 \mathrm{~h}$ postoperatively and therefore no sufficient training of waste to evacuate, even with starting the diet. Another possible cause is the decrease in intestinal transit caused by the use of anesthetics, opioids and impaired mobility postoperatively.

The hospital stay was $5 \pm 2.2$ days in these patients. According to Hur it was $8.03 \pm 1.43$ days in early feeding group and $9.9 \pm 2$ in the control group ${ }^{14}$. According to Jeong, hospitalization period was 7.4 days in early feeding group and 8.9 days in the control group ${ }^{19}$. Nascimento that evaluated early feeding after intestinal anastomoses, shows 10 days to the early group and 12 to control ${ }^{4}$. It can be seen that early feeding group has shorter hospital length of stay both in patients with gastrectomy and in other operations with intestinal anastomoses. While there is no comparison between the early group and the control group in this study, the length of stay was lower compared with the other two studies cited above ${ }^{14,19}$. This difference may be attributed to the year in which these studies were conducted because, from then on, surgical techniques and nutritional therapy were improved.

\section{CONCLUSION}

Early feeding in total or partial gastrectomy postoperative period was well tolerated by patients.

\section{REFERENCES}

1. Aguilar-Nascimento JE. Acerto: Acelerando a recuperação total pós-operatório. Rio de Janeiro: Editora Rúbio, 2011. 89 - 98p.

2. Aguilar-Nascimento JE, Campos AC, Borges A, Correia MITD, Tavares GM. Terapia Nutricional no Perioperatório. Projeto Diretrizes: Associação Médica Brasileira e Conselho Federal de Medicina. 2011. $1-16$.

3. Aguilar-NascimentoJE, CaporossiC, Serra MC, Wilson FEL.Implicações da desnutrição em cirurgia. Ver. Col. Bras. Cir 1991;18(5): 193-7.

4. Aguilar-Nascimento JE, Goelzer J. Alimentação precoce após anastomoses intestinais: riscos ou benefícios? Ver. Assoc. Med. Bras. vol.48.no.4. São Paulo, 2002. 348-52.

5. Andreollo NA, Lopes LR, Coelho Neto JS. Complicações pós operatórias após gastrectomia total no câncer gástrico. Análise de 300 pacientes. Arq Bras Cir Dig. 2011;24(2): 126-30.

6. Azevedo ALM, Costa AM. A estreita porta de entrada do Sistema Único de Saúde (SUS): uma avaliação do acesso na Estratégia de Saúde da Família. Interface (Botucatu) vol.14 no.35 Botucatu Oct./ Dec. 2010 Epub Sep 08, 2010

7. Bernardes LFM, Diogo Filho A. Early enteral feeding after upper digestive tract surgerys and clinical assessment of post-operative ileus. Biosci.J.,Uberlândia,v.24, 2008. 100-7.

8. Brito S, Dreyer E. Terapia Nutricional: Condutas do Nutricionista. São Paulo, 2003. 5 - 42.

9. Castro RCB. É possível nutrir o paciente cirúrgico no pós-operatório imediato? Como isso deve ser feito? 2012. 1. Disponível em:<http:// www.nutritotal.com.br/perguntas $/$ acao $=$ bu\&id $=656 \&$ categor ia $=32>$.

10. Corrêa ACP, Ferreira F, Cruz GSP, Pedrosa ICF.Acesso à serviços de saúde: olhar de usuários de uma Unidade de Saúde da Família. Rev. Gaúcha Enferm. (Online) vol.32 no.3 Porto Alegre Sept. 2011.451 $-157 p$

11. Department of Surgery, University Hospital Zurich, Switzerland, 2008-2009. Disponível em:<http://www.surgicalcomplication.info/ index-2.html>.

12. Hirao MMD, Tsujinaka TMD, Takeno AMD, Fujitani KMD, Kurata MRD. Paciente-controlled Dietary Schedulle Improves Clinical Outcome after Gastrectomy for Gastric Cancer. World J. Surg. 29, 853-57 (2005). DOI: 10.1007/s00268-005-7760-x

13. Hur H, Kim SG, Shim JH, Song KY, Kim W, et al. Effect of early oral feeding after gastric cancer surgery: A result of randomized clinical trial. Surgery. Volume 149, Issue 4, Pages 561-68, April 2011.

14. Hur H, Si Y, Kang WK, Kim W, Jeon HM. Effects of Early Oral Feeding on Surgical Outcomes and Recovery After Curative Surgery for Gastric Cancer: Pilot Study Results. World Journal of Surgery . 2009, Volume 33, Issue 7, pp 1454-1458.

15. Instituto nacional do Câncer (Brasil): Estadiamento. Rio de Janeiro (RJ):INCA, 2014.

16. Instituto nacional do Câncer (Brasil): Estimativas para câncer 2014. Rio de Janeiro (RJ):INCA, 2014. 
17. Instituto Nacional do Câncer (Brasil):Inquerito Brasileiro de Nutrição oncológica. Rio de Janeiro (RJ):INCA, 2013. p.4-67.

18.Instituto nacional do Câncer (Brasil): Tipos de Câncer: estômago. Rio de Janeiro (RJ):INCA, 2014.

19. Jeong O, Ryu SY, Jung MR. The safety and feasibility of early postoperative oral nutrition on the first postoperative day after gastrectomy for gastric carcinoma. Gastric Cancer (2014) 17:324-331. DOI 10.1007/s10120-013-0275-5.

20. Jo DH, Jeong O, Sun JW, Jeong MR, Ryo SY, Park YK. Feasibility Study of Early Oral Intake, after Gastrectomy for gastric Carcinoma. J Gastric Cancer 2011;11(2):101-08DDOI:10.5230/jgc.2011.11.2.101.

21. (10) Megan MK, Casey RG, Black P, koupparis AJ. Enhanced recovery after surgery (ERAS) protocols: Time to change practice? Can Urol Assoc J. 2011. 5(5): 342-48.

22. MerhiVAL,AzankAT,CrrêaB,Fogaça KP,OliveiraMRM.Acompanhamento dietatorápico durante interrnação em pacientes hospitalizados. Cad. Saúde Colet., Rio De Janeiro, 16 (4). 2008: 803 - 814.
23. Murphy PM, Blackshaw GRJC, Paris HJ, Edwuards P, Barry JD, Lewis WG. Prospective evaluation of nutritional satatus relates to body mass indices and outcomes after modified D2 gastrectomy for carcinoma. Clinical Nutrition (2004) 23, 477-83.

24. Nakeeb AE, Fikry A, Metwally TE, Fouda E, Youssef M, Ghazy $H_{\text {, }}$ et al. Early oral feeding in patients undergoing elective colonic anastomosis. International Journal of Surgery 7 (2009) 206-09.

25. Oliveira AR. Alimentação precoce no pós-operatório de cirurgia por neoplasia gástrica. Curitiba, 2007. 4 - 52.

26. Papini-Berto SJ; Burini RC. Causas da desnutrição pós gastrectomia. Arq. Gastroenterol. vol.38 no.4 São Paulo Oct./Dec. 2001:<http:// dx.doi.org/10.1590/S0004-28032001000400011 . 272-75>.

27. Silva MCS,Pereira JD. Tratado de alimentação, nutrição \& dietoterapia. 2. ed. São Paulo: Roca, 2010.

28. Waitzber DL. Dieta, nutrição e câncer. São Paulo, Rio de Janeiro, Ribeirão Preto e Belo Horizonte. 2004. 407 - 24p. 